\title{
Balkanologie
}

Balkanologie Revue d'études pluridisciplinaires

Vol. II, nº 1 | 1998

Volume II Numéro 1

\section{Interpreting the Term « National Minority »}

\section{Mihail Ivanov}

\section{(2) OpenEdition}

\section{Journals}

Electronic version

URL: http://journals.openedition.org/balkanologie/244

DOI: 10.4000/balkanologie.244

ISSN: 1965-0582

\section{Publisher}

Association française d'études sur les Balkans (Afebalk)

\section{Printed version}

Date of publication: 1 July 1998

ISSN: 1279-7952

\section{Electronic reference}

Mihail Ivanov, « Interpreting the Term « National Minority » », Balkanologie [Online], Vol. II, n 1 | 1998, Online since 02 June 2008, connection on 17 December 2020. URL : http://journals.openedition.org/ balkanologie/244; DOI : https://doi.org/10.4000/balkanologie.244

This text was automatically generated on 17 December 2020.

(C) Tous droits réservés 


\title{
Interpreting the Term « National Minority »
}

\author{
Mihail Ivanov
}

The author wishes to thank Dr. A. Orachev and Dr. E. Ivanova who, six years ago, helped him enter this slippery matter which is the subject of this text.

On October 9, 1997 in Strasbourg, President Peter Stoyanov signed on behalf of Bulgaria the Framework Convention for the Protection of National Minorities. During the days before the signing, a discussion was provoked in society which still continues and in which politicians, officials from the Ministry of Foreign Affairs, political scientists, journalists, ordinary citizens, and to a lesser degree (at least until now) specialists are participating.

2 It is gratifying that Bulgaria, even though among the last ones to do so, signed the Convention. Parliament must ratify it without hesitation. This is an international legal instrument which provides the principal framework of contemporary international standards designed to protect the wealth of ethnic, religious, and linguistic diversity, which at the same time harmonizes the development of each individual as well as the various groups of individuals with the development of society as a whole.

At the same time, it must be made known that there are certain problems connected with the Framework Convention, part of which have been manifested in the process of public discussion, and others which might manifest in the future. They require careful consideration without turning it into a pretext for delaying ratification and later implementation of the commitments made.

4 This presentation is dedicated to one of these problems, namely the problem of terminology.

\section{Is there any « national minority » in Bulgaria ?}

5 A certain confusion has resulted in our society regarding terminology which is not without reason. A number of prominent politicians and officials in charge under the 
Ministry of Foreign Affairs have stated that there are no national minorities in Bulgaria. Furthermore, a draft interpreting declaration was proposed and discussed on the highest state levels which would be made at time of signing (or ratification) of the Convention. Its text states, on one hand, that the existing ethnic, cultural, linguistic, or religious differences in the population of the Republic of Bulgaria have not led to the creation of national minorities (i.e. that there are no national minorities in Bulgaria), while on the other hand it states that the Framework Convention will be implemented with regard to the Bulgarian citizens who belong to certain minority groups, which are enumerated specifically ${ }^{1}$. Here the common sense makes us ask: since the Convention applies to national minorities, and such do not exist in Bulgaria, why state that it will be implemented? Should it not be exactly the opposite: that since there are no national minorities in Bulgaria, the Convention does not apply to it and, therefore, it will not be implemented, as the matter was handled by Luxembourg?

6 A clarification is needed and let us not sidestep this issue. The contradiction is not imaginary. It is rooted in the ambiguity of the term "national minority" itself. It is derived from the term "nation" which lead us to the question whether a specific national minority belongs to a given nation, and if so, to which ? We will illustrate this dilemma with an example from the history of the Turkish community in Bulgaria. Until 1958 it was regarded by the then active communist leadership as a Turkish national minority, which is a part of the Turkish nation. In October, 1958, the Central Committee of the Bulgarian Communist Party established its Theses on the Work of the Party among the Turkish Population. There, by following the definition of "nation" imposed by Stalin, a conclusion was made that the Turkish national minority "which will remain and continue to develop as such in the future " is not part of the Turkish bourgeois nation (there is no common territory and no common economic activities), and that it has common tasks and goals with the Bulgarian nation (but without being a part of it, because there are no common language, culture, and traditions). Thus, the solution in 1958 was : in Bulgaria there is a Turkish national minority which is neither part of the Turkish, nor part of the Bulgarian nation.

\section{Eide's definition}

7 "The most ambiguous word is "nation" " Asbjorn Eide, special reporter of the SubCommission on Prevention of Discrimination and Protection of Minorities of the United Nations, exclaimed in his report of $1992^{2}$. Numerous studies from the world literature have been dedicated to the question "What is a nation?" and have provided some most diverse answers. Even so, this entire diversity of interpretations can be summed into two basic ones. This is how Asbjorn Eide presents them in his report of $1993^{3}$ :

The two meanings of "nation" will here be given different names. "Nation" will be understood as the aggregate, permanent population of a sovereign State [T. Krejči and V. Velímský ${ }^{4}$ and Pierre Kende ${ }^{5}$ use in this case the term "political nation"] It is a technical and legal concept, linked to the notion of citizenship in its legal sense. Article 15 of the Universal Declaration of Human Rights stating that everyone has the right to a nationality ${ }^{6}$ means that everyone has the right to hold the citizenship of a State, which makes her or him a part of the nation.

8 Later Asbjorn Eide continues:

An entirely different notion of "nation" based on ethnicity, rather than citizenship, is also widely used and will here be referred to as "ethno-nation". This is a more or 
less indeterminate group, sometimes straddling the territories of two or more States, of persons who consider themselves to share certain common traditions and characteristics. Of particular importance is a common language or a common religion, and a perceived common history.

\section{The ambiguity of a term}

9 It becomes clear that the ambiguity comes from the situation that in practice the same word, "nation" is used in the sense of "political nation" as well as in the sense of "ethno-nation"7. This ambiguity is also transferred to the term "national minority".

\section{« Nation » vs. « ethno-nation »}

When we speak of "nation" as "ethno-nation", a national minority is usually taken to mean part of the (ethno-)nation on the territory of another country where this part is smaller than the rest of the population. Thus, in a number of specific cases, we reach the triad: the national minority itself, the country where it lives, and the country where the basic part of the nation or "mother-nation" is found. As an illustration we can look at the following text from the convention signed in 1992 between the Republic of Hungary and the Republic of Slovenia regarding the special rights of the Slovenian minority in Hungary and the Hungarian minority in Slovenia (Article 2, paragraph 4): «...they [the signatory parties] shall encourage the study and learning the languages, culture and history of the national minorities and their mother nation by individuals belonging to the majority nation ».

11 The perception of "nation" as an "ethno-nation" is characteristic in countries such as Germany, Hungary, Yugoslavia (Serbia), Albania, and others.

Sometimes, within the framework of this approach, we may hear in Bulgaria (especially from some of the officials from the Ministry of Foreign Affairs) that we can speak of a national minority only when part of one nation (of one ethno-nation) has remained on the territory of another country as a result of war. This, generally speaking, is not correct. There are many examples of the opposite regarding minorities which have not emerged as a result of war : the Sorbian [sic] national minority in Germany mentioned in the interpreting declaration made when Germany signed the framework Convention, a number of national minorities in Hungary (including Bulgarian), which were formed as a result of immigration, the Bulgarian national minorities in Ukraine, Moldova, and Romania, and so on. The issue that a number of minorities in Europe have appeared as a result of the World War I, is a different one ${ }^{8}$. It is appropriate to add here that in the Versailles system of peace treaties there is no mention of national minorities. Thus, for example in Part IV of the Neuilly treaty titled "Protection of Minorities ", (Article 49-57) ethnic (or racial - Article 57), religious, and linguistic minorities are mentioned".

In the context used so far (when the term "nation" is taken to mean "ethno-nation"), the idea of national minority contains the idea for multinationality of the state, where there is such minority. If we accept this approach in Bulgaria, it would mean to admit that the Bulgarian ethnic group is the Bulgarian nation and in addition to it, and outside of it, national minorities exist in Bulgaria which are parts of other nations. For example, in Bulgaria there is a Turkish national minority which is a part of the Turkish nation (i.e. the "mother-nation" is in Turkey). 


\section{« Nation » vs. « political nation »} of the member states of the Council of Europe. In these countries, whenever the word "nationality" is used, by rule it is taken as a synonym of "citizenship" in the above mentioned sense noted by A. Eide. Similarly, "national minority" means, most generally, a minority of citizens of the country (nationals of the State), who have certain characteristics which are different from those of the majority. (In the case at hand, we speak of ethnic, linguistic, or religious differences). In other words, in this context, the "national minority" is part of the "political nation", the latter consisting of all citizens of the corresponding state. We must emphasize that in most countries where the meaning of nation is adopted as "political nation", the term "national minority" is usually avoided in legislation as well as in the social context. Thus, for example, in Austria they speak of ethnic groups, in Belgium and Italy of linguistic communities, in Great Britain of racial, linguistic, and ethnic differences, in France of regional cultures. There are four linguistic communities and two basic religious communities in Switzerland. Of all 40 countries which are members of the Council of Europe, at present, the term "national minority" is used only in 17 (in most cases the term is used in the "ethno-nation" context). They are : Denmark, Germany, Poland, Estonia, Lithuania, Latvia, the Czech Republic, Slovakia, Romania, Hungary, Slovenia, Moldova, Macedonia, Albania, Ukraine, Russia, and Croatia.

In a number of European countries where the concept of "political nation" has been adopted, the one-nation principle for the country has been explicitly formulated as a constitutional principle. At the same time the coordination of this principle with the principle of respect for the existing ethnic, religious and linguistic diversity has been imposed more and more widely. A characteristic, and to a certain extent extreme, example in this respect is Switzerland. The preamble to the Swiss Constitution notes: «in the name of the Almighty God, the Swiss Confederation with the intent of strengthening the alliance of the Confederates and of maintaining and furthering the unity, strength, and honor of the Swiss nation, has adopted the following Federal Constitution $\aleph^{10}$. In 1993, in a letter to the author of this text, Mr. A. Hugentobler, then Swiss ambassador to Bulgaria wrote : « our own description of Switzerland is that of a nation bound together by the common will and respecting the diversity of its constituent part».

\section{European definitions of « minority »}

Taking into account the diversity of traditions, terminologies, and approaches regarding minorities in the countries of our continent. the European Commission for Democracy through Law recommended thefollowing definition of the term "minority" in its 1991 proposal for the European Convention for Protection of Minorities :

the term "minority" shall mean a group which is smaller in number than the rest of the population of a State, whose members, who are nationals of that State (qui ont la nationalité de cet État), have ethnical, religious, or linguistic features different from those of the rest of the population and are guided by the will to safeguard their culture, traditions, religion, or language. Any group coming within the terms of this definition shall be treated as an ethnic, religious, or linguistic minority. ${ }^{11}$ 
The approach of the countries preferring the term "national minority", however, prevailed with the Ad Hoc Committee, set up by the Council of Europe to draft the Framework Convention. At the same time, taking into account its different meanings, the following text was included in the explanatory report to the Convention: " it should also be pointed out that the framework Convention contains no definition of the notion of "national minority". It was decided to adopt a pragmatic approach based on the recognition that, at this stage, it is impossible to arrive at a definition capable of mustering general support of all Council of Europe member States $»^{12}$.

This way, the countries accepting the Convention are left with the freedom to interpret the term "national minority" for themselves according to their legal system and specific conditions.

\section{The Bulgarian case}

Let us connect the above-mentioned with the case of Bulgaria. Analysis of our Constitution shows without any ambiguity that it contains the principle of unity of nation (in the "political nation" sense). To make this more convincing, let us look at some of the Constitutional texts mentioning the term "nation" and its derivatives. The Bulgarian national flag is called in Article 167 a national flag. It is obvious that all Bulgarian citizens come under it regardless of ethnicity. According to Article 116, "State officials are executors of the nation's will and interests ». There is no doubt that this refers to the will and interests of all Bulgarian citizens. The Constitution speaks of national security, of unity of nation, the President as Head of State who "personifies the unity of the nation" (Article 92). Furthermore, it speaks of national referenda which are "carried out on the basis of common, equal and direct right to vote" (Article 10). At the same time, the Constitution contains texts to guarantee the rights of citizens which derive from the existing differences in our society regarding their ethnicity (Article 54), their mother's tongue (Article 36) and their religion (Article 37) ${ }^{13}$.

This constitutional basis provides a successful solution for the complicated and difficult task consisting of ensuring the necessary conditions under which every individual and groups of individuals can preserve and develop their individuality, including their ethnic, religious, and linguistic identity, that is, to guarantee the right of others to be different and to develop as different, and at the same time to guarantee the successful functioning and development of the national social organism, taken as a whole and in unity.

The choice made in the Bulgarian Constitution for the approach based on the concept of political nation makes groundless the concerns that the existing communities of Bulgarian citizens whose ethnicity is different from the Bulgarian one, whose mother tongue is different from the Bulgarian language, or whose religion is different from the Eastern Orthodox religion, can be perceived as such national minorities which are part of other nations. On the other hand, the approach thus chosen cannot influence the fact that in countries such as Hungary, Yugoslavia, Ukraine, Moldova and others, Bulgarians living there are perceived and treated as national minorities (in the context of nation as "ethno-nation"), since the choice in this area is an internal matter issue for each individual country and a result of its historical development and political interests. 


\section{Is there a minority in Bulgaria?}

\section{following proposal for an interpreting declaration to be presented at the signing of the} Framework Convention for the Protection of National Minorities :

The Republic of Bulgaria

noting the impossibility at this stage to arrive at a definition of the term "national minority" capable of mustering general support of all Council of Europe member States as well as the fact that not all ethnic, cultural, linguistic or religious differences necessarily lead to the emergence of national minorities,

following the principle found in the Constitution of the Republic of Bulgaria which confirms that Bulgaria is a one-nation State,

respecting the differences existing among Bulgarian citizens with regard to their ethnicity, their mother tongue, and their religion,

declares,

that it will implement the Framework Convention for the Protection of National Minorities with regard to Bulgarian citizens belonging to the ethnic, linguistic, and religious minorities who traditionally live on its territory.

With regard to the terminology which is suitable to be specified in the process of made with the approach adopted by the United Nations based on Article 27 of the International Covenant on Civil and Political Rights which states : « in those States in which ethnic, religious or linguistic minorities exist, persons belonging to such Democracy through Law) : "a minority is any group of persons resident within a sovereign State which constitutes less than half of the population of the national society and whose members share common characteristics of ethnic, religious, or linguistic nature which distinguish them from the rest of the population. »

of Article 27 of the International Covenant on Civil and Political Rights, which states more specifically: "the existence of an ethnic, religious, or linguistic minority in a given State party does not depend upon a decision by that State party, but requires to be established by objective criteria $\|^{15}$.

euphemistic and wholly motivated by psychological considerations and does not lead to any favorable consequences. Furthermore, it gives rise to distrust and insecurity among our fellow citizens whose ethnicity is not Bulgarian. ${ }^{16}$

\section{A proposal}

n October 1, 1997, this proposal was filed at the Office of the President of the Republic of Bulgaria. 


\section{NOTES}

1. Democratsiya Daily, 26/09/97.

2. Eide (Asbjorn), «Possible ways and means of facilitating the peaceful and constructive solution of problems involving minorities ", UN documents, E/CN. 4/Sub. 2/1992/37, 01/07/92.

3. Eide (Asbjorn), " Possible ways and means of facilitating the peaceful and constructive solution of problems involving minorities », UN documents, E/CN. 4/Sub. 2/1993/34, 10/08/93.

4. Krejči (Jaroslav), Velímský (Vítìzslav), Ethnic and political nations in Europe, New York : St Martin press, 1981.

5. Kende (Pierre), « Plaidoyer pour la nation politique », La Nouvelle Alternative, (19), 1990.

6. Human Rights. A Compilation of International Instruments, New York : United Nations, 1988.

7. Regarding the two perceptions of "nation", see also : Gellner (Ernest), Nations et nationalism, (first published in 1983), New York: Cornell University Press, fifth printing, 1993; Eide (Asbjorn), «Ethno-nationalism and minorities protection : the need for institutional reforms ", in The reform of international institutions for the protections of human rights, Bruxelles: Bruylant, 1993 ; Tsvetkov (P.), "The Nation in Masses-Consciousness ", History, Society, Philosophy, (4), 1991 ; Fotev (Georgi), The Other Ethnos, Sofia : Academic Publisher « Marin Drink », 1994 ; Ivanov (Mihail), « Political Nation or Ethno-nation », The Human Rights, (2), 1997.

8. A detailed review of German minorities emerging after World War I is given in the report presented by Schelter (Kurt), « Die Politik der Bundesregierung fur die deutschen Minderheiten in Ostmittel-, Ost-, und Südosteuropa einschlie㕆lich der Nachfolgestaaten der Sowjetunion ", The Situation of Ethnic Groups and Minorities in Europe, seminar on October 4-6, 1994, Bratislava.

9. Neuilly Treaty (with remarks by Dr. B. Kesyakov and D. Nikolov), Sofia : Martilen, 1991.

10. Federal Constitution of the Swiss Confederation of 29th May 1874, Federal Department of Foreign Affairs, 1991.

11. European Commission for Democracy through Law, Proposal for a European Convention for the Protection of Minorities, Strasbourg: Council of Europe documents, CDL - MIN (93) 6, 22 February 1993.

12. Framework Convention for the Protection of National Minorities and Explanatory Report, Strasbourg : Council of Europe documents. H (95) 10, February 1995.

13. Constitution of the Republic of Bulgaria, Sofia, 12 July 1991.

14. Human Rights. A Compilation of International Instruments, New York : United Nations, 1992.

15. «General Comment adopted by the Human Rights Committee under Article 40, Paragraph 4 of the International Convention on Civil and Political Rights ", Addendum, General Comment N 23 (50) (Art. 27), UN documents, CCPR/C/21/Rev.1/Add. 5, 26 April 1994.

16. See, for example, Tekirdahtsi (Busak), «Language difficulties, or ... ? ", Erevan Daily, (9), October 1997. 


\section{ABSTRACTS}

Although Bulgaria has signed the Framework Convention for the Protection of National Minority, it does recognize the existence of minority on its soil. More, the term still need a clear definition, because of the misunderstanding between « ethno » and « political » nation.

Bien que la Bulgarie ait signé la convention cadre pour la protection des minorités nationales, elle ne reconnaît pas l'existence de minorité sur son territoire. De plus, la terminologie a besoin d'une définition précise, du fait de l'amalgame entre nation « ethnique » et « politique ».

\section{AUTHOR}

\section{MIHAIL IVANOV}

Mihail Ivanov is born in 1943, Sofia. His father's family comes from Pirin Macedonia. A doctor in theoretical and mathematical physics, he spent most of his career as a researcher at the Institute of Nuclear research and Nuclear Energy (INRNE, Sofia) and at the Joint Institute of Nuclear Research (Dubna, USSR, 1976-1983). After Zhivkov's downfall, M. Ivanov contributed in founding the Committee for National Reconciliation, a non-governmental organization which fought for the restoration of the Bulgarian Turks' rights, and which was instrumental in overcoming the interethnic tension provoked by communist assimilation policies. Following Zheliu Zhelev's election to the Presidency (August 1990), he became advisor to the President on ethnic and religious issues, a position he occupied till 1997. In this capacity, he participated in several international fora on minority issues (CSCE, Council of Europe, ...), and supported the implementation of large-scale research projects on ethnic and religious minorities in Bulgaria. An associated professor at the INRNE since 1990, M. Ivanov is also a member of the Board of Directors of the International Centre for Minority Studies and Intercultural Relations (headed by Antonina Zheliaszkova) as well as of the recently set up Foundation Dr. Zheliu Zhelev. 